\title{
THE AMELIORATING EFFECTS OF GARLIC (ALLIUM SATIVUM) AGAINST LEAD (PB) INTOXICATION ON BODY WEIGHT, DRESSING PERCENTAGES, FEED CONSUMPTION AND FEED CONVERSION RATIO IN LEAD INDUCED BROILER CHICKENS
}

\author{
M. A. Hossain ${ }^{1}$, M. Mostofa ${ }^{2 *}$, M. N. Alam ${ }^{2}$, M. R. Sultana ${ }^{3}$ and M. M. Rahman ${ }^{2}$ \\ ${ }^{1}$ Department of Pharmacology and Toxicology, Sylhet Agricultural University, Sylhet-3100, Bangladesh \\ ${ }^{2}$ Department of Pharmacology, Bangladesh Agricultural University, Mymensingh, Bangladesh, ${ }^{3}$ Department of \\ Animal Husbandry and Veterinary Science, University of Rajshahi, Bangladesh
}

\begin{abstract}
Lead $(\mathrm{Pb})$ has extensive commercial and industrial use despite of its recognized as health hazard. The therapeutic application of garlic (Allium sativum) was investigated for preventing the toxic effect of lead (Pd) in lead exposed chickens. 350 commercial broiler chickens were grouped into five such as $T_{0}, T_{1}, T_{2}, T_{3}$ and $T_{4}$ consisting of 70 birds each where $T_{0}$ served as control. $\mathrm{T}_{1}$ was provided with lead acetate at $100 \mathrm{mg} / \mathrm{kg}$ body weight, $\mathrm{T}_{2}$ had $100 \mathrm{mg} / \mathrm{kg}$ lead acetate $+1 \%$ garlic supplement, $\mathrm{T}_{3}$ was fed with $100 \mathrm{mg} / \mathrm{kg}$ lead acetate $+2 \%$ garlic supplement and $\mathrm{T}_{4}$ had $100 \mathrm{mg} / \mathrm{kg}$ lead acetate $+4 \%$ garlic supplement for 42 days. Garlic was found to be capable of elimination of lead $(\mathrm{Pb})$. Analysis of variance statistically revealed that significant $(\mathrm{P}<0.01)$ lower level of live weight $(\mathrm{g})$, carcass weight $(\mathrm{g})$ and eviscerated fresh carcass weight $(\%)$ were $2015.26 \pm 49.73,1124.45 \pm 11.67$ and $60.63 \pm 3.18$, respectively in the chickens in group $\mathrm{T}_{1}$ at $42^{\text {nd }}$ day of treatment in comparison to other groups. All garlic treatment groups satisfactorily increased live weight and carcass weight. Following the application of dietary garlic, mean values of live weight $(\mathrm{g})$, carcass weight $(\mathrm{g})$ and eviscerated fresh carcass weight $(\%)$ were significantly $(\mathrm{P}<0.01)$ increased at $2156.63 \pm 74.52,1455.85 \pm 9.21$ and $63.96 \pm 2.18$ in group $\mathrm{T}_{3}$. Feed conversion ratio showed non-significant differences between different groups, but the most significant $(\mathrm{P}<0.01)$ FCR values were recorded in $\mathrm{T}_{3}$ among the treatment groups. It can be recommended from the present study that garlic might be played an active role to antagonize lead $(\mathrm{Pb})$ toxicity.
\end{abstract}

Key words: Garlic, Amelioration, lead intoxication, weight gain, feed consumption, lead induced broilers

\section{INTRODUCTION}

Lead is a blue-gray and highly toxic divalent metal that occurs naturally in the earth's crust and is spread throughout the environment by various human activities. Despite decades of intensive research, lead toxicity also remains one of the most, studied subjects of all within the fields of environmental health and environmental medicine. Widespread lead $(\mathrm{Pb})$ exposure from industrial processes, manufacturing practices, lead-contaminated paint and consumer products remains common problems in many parts of the world, despite some success in the worldwide ban of leaded gasoline (Tong et al., 2000). Lead (Pb), the most abundant toxic heavy metal in the environment, has been consequently increased due to the extensive commercial use of lead $(\mathrm{Pb})$ from prehistoric times despite its recognized hazards. Unjustified uses of this natural resource $(\mathrm{Pb})$ have adverse effect on our environment. This causes environmental degradation that may bring a threat to all forms of life including man, animal, plant or aquatic life (ATSDR, 1992). Contamination is transferred to food animals via direct or indirect exposure of lead $(\mathrm{Pb})$. Important reason for causing lead $(\mathrm{Pb})$ contamination of food animals is the deposition of contaminants to the soil or aquatic environment from vehicular emission. Chickens are susceptible to lead $(\mathrm{Pb})$ intoxication. As little as $1.0 \mathrm{mg} / \mathrm{kg}$ lead $(\mathrm{Pb})$ in the diet can cause significant depression in the growth of broiler chickens and consistent reduction in blood d-aminolevulinic acid dehydratase, an erythrocyte enzyme sensitive to lead ( $\mathrm{Pb}$ ) (Bakalli et al., 1995). Broiler chickens are vulnerable to Pb intoxication. Bakalli et al. (1995) reported the magnitude of lead toxicity in broiler chickens; and the highest and lowest deposition of lead $(\mathrm{Pb})$ concentration was detected in bone and skeletal muscle, respectively in lead exposed chickens.

The protection action of garlic against lead $(\mathrm{Pb})$ toxicity could be attributed to the antioxidant action of its sulfhydryl groups (Ashour, 2002). The assumption of oxidative stress as a mechanism in lead $(\mathrm{Pb})$ toxicity suggests that antioxidant action of garlic sulfhydryl groups might play a role in the treatment of lead $(\mathrm{Pb})$ poisoning. The bone pool contains $>95 \%$ of the total body burden, where it may be mobilized and contribute to

*Corresponding e-mail address: mostof57@yahoo.com 


\section{A. Hossain and others}

the blood lead level (BLL). The soft tissues that easily take up lead are liver, kidney, brain, and muscle. Lead is not metabolized in the body, but it may be conjugated with glutathione and excreted primarily in the urine (ATSDR, 1993). Garlic contains at least 33 sulfur compounds, several enzymes, 17 amino acids, and minerals such as selenium (Newall et al., 1996). It contains a higher concentration of sulfur compounds than any other Allium species. The sulfur compounds are responsible both for garlic's pungent odor and many of its medicinal effects. One of the most biologically active compounds, allicin (diallylthiosulfinate or diallyl disulfide) does not exist in garlic until it is crushed or cut; injury to the garlic bulb activates the enzyme allinase, which metabolizes alliin to allicin. Garlic exhibit direct antioxidant effects and enhance the serum levels of two antioxidant enzymes, catalyses and glutathione peroxides (Ide et al., 1997).Garlic constituents, allicin and S-allylcysteine, demonstrates significant antioxidant effects in vitro (Imai et al., 1994). Therefore, it was dare need to find useful protection from lead $(\mathrm{Pb})$ by using the natural products therapy to combat lead toxicity.

\section{MATERIALS AND METHODS}

The experiment was conducted in Arsenic Detection and Mitigation (ADM) Lab funded by USDA Project, Department of Pharmacology, Bangladesh Agricultural University, Mymensingh-2202 and Department of Physiology, Bangladesh Agricultural University, Mymensingh-2202 funded by Bangladesh Agricultural Research Council (BARC), Farmgate, Dhaka, Bangladesh, University Grants Commission (UGC), Bangladesh and USDA project, USA.

\section{Preparation of Poultry shed and Rearing of Experimental Birds}

The experimental animal house was prepared with the aim in order to prevent cross contamination or infectious diseases. A total of 350-day-old commercial broiler chickens (Hubbard Classic) of both sexes were collected from a local breeder farm. The chicks were housed in floor pens containing litter composed of rice husk and saw dust and received a corn-based starter diet. The chicks were reared under fluorescent lighting. Chicks had ad libitum access to feed and water. All chicks were weighed individually at day 1, 7, 14, 21, 28, 35 and 42 . The diet was formulated to have adequate amounts of all known nutrients. The chicks were fed with three types of diet consisting starter, grower and finisher. The chicks were fed a basal starter diet until 15 days of age. This was followed by a basal grower diet from day 16 to day 22 and finisher diet from day 23 to day 42 . The diets were formulated according to US National Research Council guidelines. The light was continuous during the experiment. The temperature was gradually decreased by $5^{\circ} \mathrm{F}$ at every week from $90^{\circ} \mathrm{F}$ to $75^{\circ} \mathrm{F}$ and continued throughout the experimental course. Chickens were reared under standard management conditions throughout the experimental course. The overall management of rearing was well organized in order to prevent cross contamination effectively throughout the experimental course. Daily clinical observation was also ensured.

\section{Use of Lead Acetate and Garlic (Allium Sativum) in Different Treatment Groups}

The chicks were randomly assigned to five separate pens named Group $\mathrm{T}_{0}$, Group $\mathrm{T}_{1}$, Group $\mathrm{T}_{2}$, Group $\mathrm{T}_{3}$ and Group $\mathrm{T}_{4}$, and 70 birds in each group. Each experiment was operated separately. Group $\mathrm{T}_{0}$ was kept as control group. Group $\mathrm{T}_{1}$ was given only lead acetate @ $100 \mathrm{mg} / \mathrm{kg}$. Group $\mathrm{T}_{2}$ was treated with lead acetate @ $100 \mathrm{mg} / \mathrm{kg}$ $+1 \%$ garlic supplement. Group $\mathrm{T}_{3}$ was treated with lead acetate @ $100 \mathrm{mg} / \mathrm{kg}+2 \%$ garlic supplement and Group $\mathrm{T}_{4}$ was treated with lead acetate @ $100 \mathrm{mg} / \mathrm{kg}+4 \%$ garlic supplement. The experimental course was operated for 42 uninterrupted days. Three experimental diets were formulated to have $1 \%, 2 \%$ and $4 \%$ garlic (Allium sativum) powder for Group $\mathrm{T}_{2}$, Group $\mathrm{T}_{3}$ and Group $\mathrm{T}_{4}$, respectively. Control diet was free from both dietary garlic (Allium sativum) and lead acetate. Diets were formulated from the locally commercially available ingredients. Garlic was prepared without skin and dried in a Freeze Drier Model (LABCONCO) for 72 hours, and then ground to become powder. Ten birds were sacrificed from each group on every week at Day 1, Day 7 , Day 14, day 21, day 28, day 35 and Day 42. Analytical grade lead acetate that used in this study was obtained from Merck (Germany). Garlic (Allium sativum) was locally purchased. The doses of lead acetate and garlic were based on other studies (Hanafy et al., 1994; Ashour et al., 2000Yassin et al., 2005). The garlic powder was not deodorized. 
Assessment of Body Weight (g), Body Weight Gain (g), Feed Consumption (g) and Feed Conversion Ratio

This study was performed in growing broiler chickens ( 1 to $42 \mathrm{~d}$ of age) to evaluate the effects on health condition through garlic feed supplement in lead $(\mathrm{Pb})$ toxicity induced commercial broiler chickens. All experimental birds were monitored twice a day for clinical signs of disease, mortality and gross pathological changes in different organs during the experimental course. The Physical condition of the experimental birds was monitored regularly. Body weight of the day old chicks was taken immediately after arrival. Birds were weighed at every sampling date during the experimental course. First body weight was measured on day1 and next body weight, body weight gain, feed consumption and feed conversion ratio of the control and treated birds were measured at 7 days interval up to day 42 (at day 7, day 14, day 21, day 28, day 35 and day 42). Feed conversion ratio (FCR) was calculated as feed-to-gain ratio, on the $7^{\text {th }}, 14^{\text {th }}, 21^{\text {st }}, 28^{\text {th }}, 35^{\text {th }}$ and $42^{\text {nd }}$ days and over days from 1 to $42^{\text {nd }}$ days of the experiment.

\section{Assessment of carcass quality}

On day 42 , the birds were fasted overnight, weighed the following morning prior to euthanization. The birds were defeathered completely using warm water. They were then decapitated and eviscerated and weighed again to obtain the eviscerated weights. All body organs were separated and weighed to obtain their fresh weights. The different parts of the carcass included the thigh, drumstick, breast meat, wing meat, neck, head, liver, gizzards, heart, abdominal fat, spleen and bursa. The weights $(\mathrm{g})$ of the different parts were expressed as percentage proportion of live weights. During processing, the results of the carcass yields were evaluated statistically.

\section{Statistical Analysis}

The statistical analysis of variance was analyzed by Duncan's Multiple Range Test (DMRT) using the General Linear Models (GLM) procedure of SAS software (SAS, 1985). Duncan's multiple range tests were also used to locate the calculated means that are significantly different. Results were displayed as means \pm standard error (SE).

\section{RESULTS AND DISCUSSION}

Ameliorating effect of lead $(\mathrm{Pb})$ by the therapeutic use of garlic supplement on growth performances of broiler chickens was studied and compared with control group and lead acetate group in the present study. The carcass yield characteristics and organ traits of different groups are presented in Table 1 . The results were more satisfactory in 2\% garlic supplemented and lead acetate group $\left(\mathrm{T}_{3}\right)$ among the different treatment groups $\left(\mathrm{T}_{2}, \mathrm{~T}_{3}\right.$ and $\mathrm{T}_{4}$ ). There were significant $(\mathrm{P}<0.01)$ variation between live weight and carcass weight among the different treatment groups in comparison to the control groups. Lead acetate @ $100 \mathrm{mg} / \mathrm{kg}$ treatment group $\left(\mathrm{T}_{1}\right)$ significantly $(\mathrm{P}>0.05)$ reduced the live weight and carcass weight in comparison with the control group $\left(\mathrm{T}_{0}\right)$ at $42^{\text {nd }}$ day of treatment.

Following the application of different therapeutic doses of dietary garlic in lead $(\mathrm{Pb})$ toxicity induced broiler chickens, the live weight $(\mathrm{g})$ and carcass weight $(\mathrm{g})$ increased satisfactorily in different garlic treatment groups. However, the most significant increased $(\mathrm{P}<0.01)$ values of live weight and carcass weight was recorded group $\mathrm{T}_{3}$ in comparison with the other treatment groups at $42^{\text {nd }}$ day of treatment. Accordingly, eviscerated fresh carcass weight $(\%)$ was also found significantly $(\mathrm{P}<0.01)$ highest values $(63.962 \pm 0.182)$ in group $\mathrm{T}_{3}$ in comparison to the other treatment groups $\left(\mathrm{T}_{2}\right.$ and $\left.\mathrm{T}_{4}\right)$.

Analysis of variance statistically revealed that significant $(\mathrm{P}<0.01)$ lower level of live weight $(\mathrm{g})$, carcass weight $(\mathrm{g})$ and eviscerated fresh carcass weight $(\%)$ were $2015.26 \pm 49.73,1124.45 \pm 11.67$ and $60.63 \pm 3.18$, respectively in chickens in group $\mathrm{T}_{1}$ at $42^{\text {nd }}$ day of treatment in comparison to the other treatment groups. However, following the application of dietary garlic in lead toxicity induced broiler chickens, the mean values of live weight $(\mathrm{g})$, carcass weight $(\mathrm{g})$ and eviscerated fresh carcass weight $(\%)$ were significantly increased at $2156.63 \pm 74.52,1455.85 \pm 9.21$ and $63.96 \pm 2.18$ in group $\mathrm{T}_{3}$. But no significant $(\mathrm{P}>0.05)$ differences were detected in interior organs (Table 1). 


\section{A. Hossain and others}

Table 1. Effect of Garlic on carcass weight (\%) in Lead Toxicity Induced Broiler Chicken

\begin{tabular}{|c|c|c|c|c|c|}
\hline Variables & Control & $\begin{array}{l}\text { Lead Acetate @ } \\
100 \mathrm{mg} / \mathrm{Kg}\left(\mathrm{T}_{1}\right)\end{array}$ & $\begin{array}{l}\text { Lead Acetate } \\
@ 100 \mathrm{mg} / \mathrm{Kg} \\
+1 \% \text { Garlic } \\
\text { supplement (T2) }\end{array}$ & $\begin{array}{l}\text { Lead Acetate } \\
@ 100 \mathrm{mg} / \mathrm{Kg} \\
+2 \% \text { Garlic } \\
\text { supplement (T3) }\end{array}$ & $\begin{array}{l}\text { Lead Acetate } \\
\text { @ } 100 \mathrm{mg} / \mathrm{Kg} \\
+4 \% \text { Garlic } \\
\text { supplement } \\
\text { (T4) }\end{array}$ \\
\hline Live weight (g) & $2213.62 \pm 28.67^{\mathrm{a}}$ & $2015.26 \pm 49.73^{b}$ & $2098.87 \pm 43.17^{\mathrm{c}}$ & $2156.63 \pm 74.52^{\mathrm{a}}$ & $2107.25 \pm 36.67^{c}$ \\
\hline Carcass Weight (g) & $1572.95 \pm 11.54^{\mathrm{a}}$ & $1124.45 \pm 11.67^{b}$ & $1142.74 \pm 10.04^{\mathrm{c}}$ & $1455.85 \pm 9.21^{\mathrm{a}}$ & $1327.95 \pm 12.24^{\mathrm{c}}$ \\
\hline $\begin{array}{l}\text { Eviscerated Carcass } \\
\text { Weight }(\%)\end{array}$ & $66.87 \pm 1.18^{\mathrm{a}}$ & $60.63 \pm 3.18^{b}$ & $59.26 \pm 2.18^{\mathrm{c}}$ & $63.96 \pm 2.18^{\mathrm{a}}$ & $60.48 \pm 3.18^{c}$ \\
\hline Thigh (\%) & $12.99 \pm 0.18^{\mathrm{a}}$ & $10.54 \pm 0.15^{\mathrm{a}}$ & $10.97 \pm 0.17^{\mathrm{a}}$ & $11.75 \pm 0.13^{\mathrm{a}}$ & $11.54 \pm 0.12^{\mathrm{a}}$ \\
\hline Drumstick (\%) & $8.84 \pm 0.08^{\mathrm{a}}$ & $7.45 \pm 0.16^{\mathrm{a}}$ & $7.58 \pm 0.11^{\mathrm{a}}$ & $8.24 \pm 0.09^{\mathrm{a}}$ & $8.14 \pm 0.08^{\mathrm{a}}$ \\
\hline Breast meat (\%) & $17.62 \pm 0.02^{\mathrm{a}}$ & $15.24 \pm 0.17^{b}$ & $15.57 \pm 0.08^{\mathrm{a}}$ & $16.57 \pm 0.02^{\mathrm{a}}$ & $15.39 \pm 0.01^{\mathrm{a}}$ \\
\hline Wing meat $(\%)$ & $9.61 \pm 0.51^{\mathrm{a}}$ & $8.57 \pm 0.52^{\mathrm{a}}$ & $8.95 \pm 0.52^{\mathrm{a}}$ & $8.95 \pm 0.02^{\mathrm{a}}$ & $8.57 \pm 0.03^{\mathrm{a}}$ \\
\hline $\operatorname{Neck}(\%)$ & $6.94 \pm 0.43^{\mathrm{a}}$ & $5.91 \pm 0.08^{\mathrm{a}}$ & $6.18 \pm 0.15^{\mathrm{a}}$ & $9.41 \pm 0.25^{\mathrm{a}}$ & $6.28 \pm 0.03^{\mathrm{a}}$ \\
\hline Head $(\%)$ & $0.92 \pm 0.04^{\mathrm{a}}$ & $0.91 \pm .05^{\mathrm{a}}$ & $0.91 \pm 0.02^{\mathrm{a}}$ & $0.92 \pm 0.02^{\mathrm{a}}$ & $0.91 \pm 0.06^{\mathrm{a}}$ \\
\hline Liver (\%) & $2.02 \pm 0.09^{\mathrm{a}}$ & $1.91 \pm 0.07^{\mathrm{b}}$ & $1.99 \pm 0.08^{\mathrm{b}}$ & $1.98 \pm 0.02^{\mathrm{a}}$ & $1.58 \pm 0.02^{\mathrm{a}}$ \\
\hline Gizzard (\%) & $0.94 \pm 0.02^{\mathrm{a}}$ & $1.02 \pm 0.03^{\mathrm{a}}$ & $0.97 \pm 0.07^{\mathrm{a}}$ & $0.96 \pm 0.03^{\mathrm{a}}$ & $0.95 \pm 0.048^{\mathrm{a}}$ \\
\hline Heart $(\%)$ & $0.53 \pm 0.06^{\mathrm{a}}$ & $0.56 \pm 0.03^{\mathrm{a}}$ & $0.57 \pm 0.02^{\mathrm{a}}$ & $0.56 \pm 0.04^{\mathrm{a}}$ & $0.56 \pm 0.042^{\mathrm{a}}$ \\
\hline Abdominal fat $(\%)$ & $0.24 \pm 0.07^{\mathrm{a}}$ & $0.45 \pm 0.033^{\mathrm{a}}$ & $0.34 \pm 0.07^{\mathrm{a}}$ & $0.27 \pm 0.06^{\mathrm{a}}$ & $0.35 \pm 0.07^{\mathrm{a}}$ \\
\hline Spleen $(\%)$ & $0.07 \pm 0.05^{\mathrm{a}}$ & $0.11 \pm 0.07^{\mathrm{a}}$ & $0.08 \pm 0.03^{\mathrm{a}}$ & $0.09 \pm 0.07^{\mathrm{a}}$ & $0.09 \pm 0.08^{\mathrm{a}}$ \\
\hline $\begin{array}{l}\text { Bursa of Fabricious } \\
(\%)\end{array}$ & $0.09 \pm 0.02^{\mathrm{a}}$ & $0.05 \pm .01^{\mathrm{a}}$ & $0.05 \pm 0.05^{\mathrm{a}}$ & $0.08 \pm 0.03^{\mathrm{a}}$ & $0.08 \pm 0.09^{\mathrm{a}}$ \\
\hline
\end{tabular}

$\mathrm{T}_{0}, \mathrm{~T}_{1}, \mathrm{~T}_{2}, \mathrm{~T}_{3}$ and $\mathrm{T}_{4}$ indicates Control, Lead Acetate @ 100mg/Kg, Lead Acetate @ 100mg/Kg + 1\% Garlic supplement, Lead Acetate @ 100mg/Kg + 2\% Garlic supplement and Lead Acetate @ 100mg/Kg + 4\% Garlic supplement groups, respectively. Values in the figures indicate mean \pm Standard error (SE). Means belonging the same superscripts did not differ significantly. Each value is the mean of 10 birds. Data were calculated at $99 \%$ level of significance $(\mathrm{P}<0.01)$.

Average weekly body weight gain in different groups showed significant differences. Feed conversion ratio showed non-significant differences between different groups. Results of body weight of the birds are presented in Table 2. The mean body weight of broiler chickens of only Lead Acetate group was significantly $(\mathrm{P}<0.01)$ lowered. The most significant increased $(\mathrm{P}>0.05)$ values of body weight $(2156.63 \pm 74.55)$ was recorded in group $\mathrm{T}_{3}$ in comparison with the other treatment groups (Table 2). Growth performance e.g., body weight, body weight gain, feed intake, feed conversion and feed conversion ratio are shown in Table 3 . The most significant $(\mathrm{P}<0.01)$ FCR values were recorded from group $\mathrm{T}_{3}$.

In the present study it was shown that the addition of garlic supplement at the different doses increased the weight gain in comparison to the lead treated group. Corresponding improvements in feed conversion efficiency were shown in the present study. Feed consumption was also affected significantly in different treatment groups. The live body weight gain was notably lowered in comparison with control groups. The birds on the control diets had significantly $(\mathrm{p}<0.01)$ higher body weight, body weight gain, feed consumption and feed conversion ratio 


\section{Ameliorating effects of garlic against lead intoxication on body weight}

than the birds on the other diets. Thus the addition of garlic to the diet tended to reverse the depressive effect of lead. It may be concluded that $2 \%$ garlic supplement to the diet would be more effective in overcoming the growth inhibitory effect resulted from lead intoxication.

Table 2. The effects of Garlic on body weight (g) in Lead Toxicity Induced Broiler Chicken

\begin{tabular}{|c|c|c|c|c|c|c|c|}
\hline \multirow[t]{2}{*}{ Treatment } & \multicolumn{7}{|c|}{ Mean \pm SE } \\
\hline & Day 1 & Day 7 & Day 14 & Day 21 & Day 28 & Day 35 & Day 42 \\
\hline $\mathrm{T}_{0}$ & $38.22 \pm 0.59^{\mathrm{a}}$ & $153.14 \pm .58^{\mathrm{a}}$ & $356.29 \pm 4.19^{\mathrm{a}}$ & $707.45 \pm 6.46^{\mathrm{a}}$ & $\begin{array}{l}1218.89 \pm 20 \\
88^{\mathrm{a}}\end{array}$ & $1774.17 \pm 52.84^{\mathrm{a}}$ & $2213.62 \pm 28.67^{\mathrm{a}}$ \\
\hline $\mathrm{T}_{1}$ & $39.37 \pm 2.82^{\mathrm{a}}$ & $141.26 \pm 3.29^{b}$ & $319.47 \pm 35.19^{b}$ & $616.59 \pm 24.94^{\mathrm{b}}$ & $\begin{array}{l}1075.23 \pm 15 \\
92^{\mathrm{a}}\end{array}$ & $1525.33 \pm 32.52^{\mathrm{b}}$ & $2015.26 \pm 49.73^{b}$ \\
\hline $\mathrm{T}_{2}$ & $36.28 \pm 0.46^{\mathrm{a}}$ & $141.26 \pm 3.11^{\mathrm{b}}$ & $318.59 \pm 34.54^{b}$ & $605.78 \pm 14.12^{\mathrm{b}}$ & $\begin{array}{l}1094.33 \pm 20 \\
32^{\mathrm{b}}\end{array}$ & $1574.29 \pm 64.47^{\mathrm{b}}$ & $2098.87 \pm 43.17^{b}$ \\
\hline $\mathrm{T}_{3}$ & $36.13 \pm 0.67^{\mathrm{a}}$ & $140.25 \pm 2.41^{\mathrm{b}}$ & $326.47 \pm 35.67^{\mathrm{a}}$ & $646.86 \pm 10.29^{\mathrm{a}}$ & $\begin{array}{l}1124.67 \pm 31 \\
39^{\mathrm{a}}\end{array}$ & $1552.49 \pm 62.57^{\mathrm{b}}$ & $2156.63 \pm 74.55^{a}$ \\
\hline $\mathrm{T}_{4}$ & $37.87 \pm 0.77^{\mathrm{a}}$ & $144.52 \pm 1.89^{b}$ & $311.68 \pm 34.12^{\mathrm{a}}$ & $624.49 \pm 23.49^{\mathrm{a}}$ & $\begin{array}{l}1102.79 \pm 21 \\
08^{\mathrm{a}}\end{array}$ & $1527.58 \pm 53.27^{b}$ & $2107.25 \pm 36.67^{\mathrm{a}}$ \\
\hline
\end{tabular}

$\mathrm{T}_{0}, \mathrm{~T}_{1}, \mathrm{~T}_{2}, \mathrm{~T}_{3}$ and $\mathrm{T}_{4}$ indicates Control, Lead Acetate @ 100mg/Kg, Lead Acetate @ 100mg/Kg + 1\% Garlic supplement, Lead Acetate @ 100mg/Kg + 2\% Garlic supplement and Lead Acetate @ 100mg/Kg + 4\% Garlic supplement groups, respectively. Values in the figures indicate mean \pm Standard error (SE). Means belonging the same superscripts did not differ significantly. Each value is the mean of 10 birds. Data were calculated at $99 \%$ level of significance $(\mathrm{P}<0.01)$

Table 3. The effects of Garlic on Feed Consumption (g), Body Weight Gain (g) and Feed Conversion Ratio (feed/live weight gain) in Lead Toxicity Induced Broiler Chickens

\begin{tabular}{|c|c|c|c|c|c|c|}
\hline \multirow[t]{3}{*}{ Day } & \multirow[t]{3}{*}{ Parameters } & \multicolumn{5}{|c|}{ Treatment Groups } \\
\hline & & $\operatorname{Control}\left(\mathrm{T}_{0}\right)$ & $\begin{array}{l}\text { Lead Acetate @ } \\
100 \mathrm{mg} / \mathrm{Kg}\left(\mathrm{T}_{1}\right)\end{array}$ & $\begin{array}{l}\text { Lead Acetate @ } \\
100 \mathrm{mg} / \mathrm{Kg}+1 \% \\
\text { Garlic } \\
\text { supplement }\left(\mathrm{T}_{2}\right)\end{array}$ & $\begin{array}{l}\text { Lead Acetate @ } \\
100 \mathrm{mg} / \mathrm{Kg}+ \\
2 \% \text { Garlic } \\
\text { supplement } \\
\left(\mathrm{T}_{3}\right)\end{array}$ & $\begin{array}{l}\text { Lead Acetate } \\
@ 100 \mathrm{mg} / \mathrm{Kg} \\
+4 \% \text { Garlic } \\
\text { supplement } \\
\left(\mathrm{T}_{4}\right)\end{array}$ \\
\hline & & Mean \pm SE & Mean \pm SE & Mean \pm SE & Mean \pm SE & Mean \pm SE \\
\hline 1 & Body Weight & $38.20 \pm 0.59^{\mathrm{a}}$ & $39.37 \pm 2.82^{\mathrm{a}}$ & $36.20 \pm 0.46^{\mathrm{a}}$ & $36.10 \pm 0.674^{b}$ & $37.80 \pm 0.772^{\mathrm{ab}}$ \\
\hline \multirow[t]{4}{*}{7} & Body Weight & $153.10 \pm 2.58^{\mathrm{a}}$ & $141.2 \pm 3.29^{\mathrm{b}}$ & $140.2 \pm 3.11^{\mathrm{b}}$ & $144.5 \pm 2.41^{\mathrm{b}}$ & $139.9 \pm 1.89^{\mathrm{b}}$ \\
\hline & Body Weight Gain & $114.9 \pm 2.32^{\mathrm{a}}$ & $101.86 \pm 2.9^{\mathrm{a}}$ & $104.2 \pm 3.34^{\mathrm{b}}$ & $108.6 \pm 2.29^{\mathrm{b}}$ & $102.5 \pm 1.84^{\mathrm{b}}$ \\
\hline & Feed Consumption & $156.2 \pm 5.65^{\mathrm{a}}$ & $119.5 \pm 4.07^{\mathrm{b}}$ & $119.9 \pm 6.74^{\mathrm{b}}$ & $138.4 \pm 5.36^{\mathrm{c}}$ & $124.3 \pm 3.59^{\mathrm{b}}$ \\
\hline & Feed conversion ratio & $1.36 \pm 0.06^{\mathrm{a}}$ & $1.18 \pm 0.05^{\mathrm{b}}$ & $1.15 \pm 0.07^{\mathrm{b}}$ & $1.27 \pm 0.07^{\mathrm{c}}$ & $1.22 \pm 0.04^{\mathrm{c}}$ \\
\hline
\end{tabular}




\section{A. Hossain and others}

\begin{tabular}{|c|c|c|c|c|c|c|}
\hline \multirow[t]{4}{*}{14} & Body Weight & $356.20 \pm 4.19^{\mathrm{a}}$ & $319.45 \pm 35.19^{b}$ & $318.5 \pm 34.54^{\mathrm{b}}$ & $326.4 \pm 35.67^{\mathrm{a}}$ & $311.6 \pm 34.12^{\mathrm{a}}$ \\
\hline & Body Weight Gain & $203.2 \pm 19.46^{\mathrm{a}}$ & $178.4 \pm 18.37^{\mathrm{b}}$ & $178.5 \pm 24.21^{\mathrm{b}}$ & $182.3 \pm 19.14^{\mathrm{b}}$ & $173.3 \pm 17.98^{\mathrm{b}}$ \\
\hline & Feed Consumption & $314.2 \pm 33.22^{\mathrm{a}}$ & $242.3 \pm 26.0^{\mathrm{b}}$ & $242.4 \pm 25.74^{\mathrm{b}}$ & $293.3 \pm 33.96^{\mathrm{c}}$ & $243.4 \pm 26.56^{\mathrm{b}}$ \\
\hline & Feed conversion ratio & $1.55 \pm 0.14^{\mathrm{a}}$ & $1.37 \pm 0.13^{\mathrm{b}}$ & $1.36 \pm 0.09^{b}$ & $1.62 \pm 0.15^{\mathrm{c}}$ & $1.42 \pm 0.15^{\mathrm{b}}$ \\
\hline \multirow[t]{4}{*}{21} & Body Weight & $707.40 \pm 16.46^{\mathrm{a}}$ & $616.5 \pm 24.94^{\mathrm{b}}$ & $605.7 \pm 14.12^{\mathrm{b}}$ & $646.8 \pm 10.29^{\mathrm{a}}$ & $624.4 \pm 23.49^{\mathrm{a}}$ \\
\hline & Body Weight Gain & $351.2 \pm 16.17^{\mathrm{a}}$ & $297.3 \pm 18.59^{b}$ & $287.2 \pm 12.19^{b}$ & $320.8 \pm 9.98^{\mathrm{b}}$ & $312.9 \pm 16.08^{b}$ \\
\hline & Feed Consumption & $545.4 \pm 14.11^{\mathrm{a}}$ & $432.2 \pm 14.21^{\mathrm{b}}$ & $419.3 \pm 24.1^{\mathrm{b}}$ & $467.9 \pm 20.8^{\mathrm{b}}$ & $448.5 \pm 30.03^{b}$ \\
\hline & Feed conversion ratio & $1.57 \pm 0.04^{\mathrm{a}}$ & $1.46 \pm 0.07^{\mathrm{a}}$ & $1.46 \pm 0.07^{\mathrm{a}}$ & $1.47 \pm 0.08^{\mathrm{a}}$ & $1.44 \pm 0.07^{\mathrm{a}}$ \\
\hline \multirow[t]{4}{*}{28} & Body Weight & $1218.80 \pm 20.88^{\mathrm{a}}$ & $1075.2 \pm 15.92^{\mathrm{a}}$ & $1094.3 \pm 20.3^{b}$ & $1124.6 \pm 31.39^{\mathrm{a}}$ & $1102.7 \pm 21.08^{\mathrm{a}}$ \\
\hline & Body Weight Gain & $511.8 \pm 19.76^{\mathrm{a}}$ & $458.4 \pm 18.78^{\mathrm{b}}$ & $488.6 \pm 12.12^{\mathrm{b}}$ & $478.2 \pm 16.94^{\mathrm{b}}$ & $478.6 \pm 10.93^{\mathrm{b}}$ \\
\hline & Feed Consumption & $837.4 \pm 29.99^{\mathrm{a}}$ & $814.7 \pm 26.59^{\mathrm{a}}$ & $714.8 \pm 28.4^{\mathrm{b}}$ & $776.2 \pm 20.69^{b}$ & $666.5 \pm 24.65^{\mathrm{c}}$ \\
\hline & Feed conversion ratio & $1.65 \pm 0.05^{\mathrm{a}}$ & $1.78 \pm 0.06^{\mathrm{a}}$ & $1.47 \pm 0.06^{\mathrm{b}}$ & $1.63 \pm 0.09^{\mathrm{a}}$ & $1.41 \pm 0.05^{\mathrm{b}}$ \\
\hline \multirow[t]{4}{*}{35} & Body Weight & $1774.10 \pm 52.84^{\mathrm{a}}$ & $1595.3 \pm 32.52^{\mathrm{b}}$ & $1574.2 \pm 64.47^{\mathrm{b}}$ & $1552.4 \pm 62.57^{b}$ & $1527.5 \pm 53.27^{b}$ \\
\hline & Body Weight Gain & $555.9 \pm 26.17^{\mathrm{a}}$ & $474.2 \pm 35.05^{\mathrm{b}}$ & $479.9 \pm 27.93^{\mathrm{b}}$ & $427.9 \pm 22.04^{\mathrm{b}}$ & $428.9 \pm 21.41^{\mathrm{b}}$ \\
\hline & Feed Consumption & $885.6 \pm 36.2^{a}$ & $766.4 \pm 13.07^{\mathrm{b}}$ & $731.4 \pm 18.4^{\mathrm{b}}$ & $715.4 \pm 25.77^{\mathrm{b}}$ & $655.2 \pm 18.15^{\mathrm{c}}$ \\
\hline & Feed conversion ratio & $1.59 \pm 0.04^{\mathrm{a}}$ & $1.62 \pm 0.12^{\mathrm{a}}$ & $1.55 \pm 0.12^{\mathrm{a}}$ & $1.68 \pm 0.09^{\mathrm{a}}$ & $1.54 \pm 0.06^{\mathrm{a}}$ \\
\hline \multirow[t]{4}{*}{42} & Body Weight & $2213.60 \pm 28.67^{\mathrm{a}}$ & $2015.2 \pm 49.73^{\mathrm{b}}$ & $2098.8 \pm 43.17^{\mathrm{b}}$ & $2156.6 \pm 74.5^{\mathrm{a}}$ & $\begin{array}{l}2107.2584 \pm 36 \\
6723^{a}\end{array}$ \\
\hline & Body Weight Gain & $439.8 \pm 51.01^{\mathrm{a}}$ & $419.9 \pm 33.64^{\mathrm{b}}$ & $524.6 \pm 15.37^{c}$ & $604.3 \pm 22.22^{\mathrm{c}}$ & $580.6 \pm 15.49^{c}$ \\
\hline & Feed Consumption & $724.8 \pm 134.2^{\mathrm{a}}$ & $639.9 \pm 23.52^{\mathrm{b}}$ & $769.3 \pm 34.25^{\mathrm{a}}$ & $865.6 \pm 32.51^{\mathrm{c}}$ & $825.4 \pm 28.74^{\mathrm{c}}$ \\
\hline & Feed conversion ratio & $1.67 \pm 0.22^{\mathrm{a}}$ & $1.53 \pm 0.15^{\mathrm{a}}$ & $1.47 \pm 0.06^{\mathrm{b}}$ & $1.44 \pm 0.13^{\mathrm{b}}$ & $1.44 \pm 0.11^{\mathrm{b}}$ \\
\hline \multirow[t]{3}{*}{$1-42$} & $\begin{array}{l}\text { Total Feed } \\
\text { Consumption }\end{array}$ & $3765.17 \pm 114.2^{\mathrm{a}}$ & $3015.86 \pm 157.42^{\mathrm{b}}$ & $2997.16 \pm 113.47^{\mathrm{c}}$ & $3416.89 \pm 86.11^{\mathrm{a}}$ & $\underset{c}{2873.92 \pm 90.29}$ \\
\hline & $\begin{array}{l}\text { Body } \\
\text { Weight Gain }\end{array}$ & $2175.43 \pm 16.29^{\mathrm{a}}$ & $1975.83 \pm 35.51^{b}$ & $2062.61 \pm 22.49^{\mathrm{a}}$ & $2120.54 \pm 22.41^{\mathrm{a}}$ & $\underset{\mathrm{a}}{2070.13 \pm 31.16}$ \\
\hline & Feed conversion ratio & $1.74 \pm 0.05^{\mathrm{a}}$ & $1.54 \pm 0.17^{\mathrm{b}}$ & $1.46 \pm 0.11^{\mathrm{c}}$ & $1.62 \pm 0.02^{\mathrm{a}}$ & $1.39 \pm 0.15^{\mathrm{c}}$ \\
\hline
\end{tabular}

$\mathrm{T}_{0}, \mathrm{~T}_{1}, \mathrm{~T}_{2}, \mathrm{~T}_{3}$ and $\mathrm{T}_{4}$ indicates Control, Lead Acetate @ 100mg/Kg, Lead Acetate @ 100mg/Kg + 1\% Garlic supplement, Lead Acetate @ 100mg/Kg + $2 \%$ Garlic supplement and Lead Acetate @ 100mg/Kg + $4 \%$ Garlic supplement groups, respectively. Values in the figures indicate mean \pm Standard error (SE). Means belonging the same superscripts did not differ significantly.Each value is the mean of 10 birds. Data were calculated at $99 \%$ level of significance $(\mathrm{P}<0.01)$

The results from the present study are in agreement with Yang et al. (2001). Tollba et al. (2003) reported that garlic act as a natural feed additive, improved broilers growth and feed conversion ratio (FCR). The results found in this study are in agreement with the earlier reports of Baidya et al. (1994) and Mandal et al. (1994) who 
observed the similar influence on carcass yield. The present study findings also revealed that there was no significant $(\mathrm{P}>0.05)$ differences in the weight of liver, heart, gizzard and spleen among the different groups. These findings partially support the findings of Mohan et al., (1996). The findings of reducing body weight in lead toxicity in the present experiment were almost similar to the findings of Szymezak et al. (1983) who reported reduced weight gain after intoxication with lead acetate. Garlic increased the body weight and feed consumption (Mohamed et al., 2000). Previous studies have reported decreased weight gain and feed intake and an increased feed: gain ratio in lead exposed chickens (Bakalli et al., 1995 and Khan et al., 1996). The addition of garlic to the diet tended to reverse the depressive effect of lead $(\mathrm{Pb})$. Therefore, it can be concluded from the present study that regular intake of garlic in a certain percentage may be beneficial in reducing the toxic effects of lead $(\mathrm{Pb})$ in lead-exposed chickens.

\section{REFERENCES}

1. Ashour A (2002). Can garlic lobes, olive oil or black seed oil offer protection for some serum biochemical constituents against lead toxicity in rabbits. al-Aqsa University 6: 74-95.

2. ATSDR (Agency for Toxic Substances and Disease Registry) (1992). Case studies in Environmental Medicine Lead toxicity. U.S. Department of Health and Human Services (September), pp.1-21.

3. ATSDR (Agency for Toxic Substances and Disease Registry) (1993). Toxicological profile for lead, Update. Prepared by Clement International Corporation under contact no. 205-88-060 for ATSDR, U.S. Public Health Services, Atlanta, GA.

4. Baidya N, Mandal L, Sarker SK and Banerjee GC (1994). Combined feeding of antibiotic and probiotic on the performance of broiler. Indian Journal of Poultry Science 29: 228-231.

5. Bakalli RI, Pesti GM and Ragland WL (1995). The magnitude of lead toxicity in broiler chickens. Veterinary and human toxicology 37:15-19.

6. Hanafy MS, Shalaby SM, el-Fouly MA, Abd el-Aziz MI and Soliman FA (1994). Effect of garlic on lead contents in chicken tissues. Dtsch Tierarztl Wochenschr 101(4): 157-158.

7. Ide N and Lau BH (1997). Garlic compounds protect vascular endothelial cells from oxidized low density lipoprotein induced injury. Journal of Pharmacology and Pharmacotherapeutics 49: 908-911.

8. Imai J, Ide N, Nagae S,Moriguchi T,Matsuura H and Itakura Y (1994). Antioxidant and radical scavenging effects of aged garlic extract and its constituents. Planta Medica 60: 417-420.

9. Khan KH, Ahmad N, Sial JK and Khan MI (1996). Ground water pollution by heavy metals. Science and Technology Development 14: 1-5.

10. Mandal Sk, Biswas JK and Mandal L (1994). Efficiency of different growth promoters on the performance of broilers. Indian Journal of Poultry Science 92: 13-17.

11. Mohamed FR, Siam SMS and El-Din AKA (2000). The influence of garlic and onion on the productive performance and some physiological traits of laying hens. Egyptian Poultry Science Journal 20(1): 123-144.

12. Mohan B, Kadirevel R,Natarajan A and Bhaskaran M (1996). Effect of Probiotics supplementation on growth nitrogen utilization and serum choclesterol in broilers. British Poultry Science 37: 395-401.

13. Newall CA and Anderson LA and Phillipson JD (1996). Herbal medicines: a guide for health-care professionals. London: Pharmaceutical Press, ix, 296.

14. SAS Institute (1985). SAS User's Guide: Statistics. Version 5 Edition. SAS Institute Inc., Cary, NC.

15. Szymezak J, Zechalko A and Biernat J (1983). Effect of fodder fat type on blood plasma lipids in mice intoxicated with lead. Bromatol Chem Toksykol 16 (2): 98-94.

16. Tollba AAH and Hassan MSH (2003). Using some natural additives to improve physiological and productive performance of broiler chicks under high temperature conditions. Black cumin (Nigella sativa) or garlic (Allium sativam). Poultry Science 23: 327-340.

17. Tong S, Schirnding Y and Prapamontol T (2000). Environmental Lead Exposure: A Public Health Problem of Global Dimensions. Bulletin of the World Health Organization 78: 1068-1077.

18. Yang J, Mosby DE, Casteel SW and Blancher RW (2001). Lead immobilization using phosphoric acid in a smelter-contaminated urban soil. Environmental Science \& Technology 35: 3553 -3559.

19. Yassin MM (2005). Prophylactic efficacy of crushed garlic lobes, black seed or olive oils on cholinesterase activity in central nervous system parts and serum of lead intoxicated rabbits. Turkish Journal of Biology 29(3): 173-180. 